\title{
Retraction Note: Ulnar malignant peripheral nerve sheath tumour diagnosis in a mixed- breed dog as a model to study human: histologic, immunohistochemical, and clinicopathologic study
}

\author{
Abbas Tavasoly ${ }^{1}$, Javad Javanbakht ${ }^{*}$, Fariba Khaki ${ }^{1}$, Ehsan Hosseini ${ }^{2}$, Alimohammad Bahrami ${ }^{2}$, \\ Mehdi Aghamohammad Hassan ${ }^{3}$ and Mohammadmehdi Mirabad ${ }^{3}$
}

The Editor-in-Chief and Publisher have retracted this article [1] because the scientific integrity of the content cannot be guaranteed. An investigation by the Publisher found it to be one of a group of articles we have identified as showing evidence suggestive of attempts to subvert the peer review and publication system to inappropriately obtain or allocate authorship. This article showed evidence of plagiarism (most notably from the articles cited [2-6]) and peer review and authorship manipulation.

\section{Author details}

${ }^{1}$ Department of Pathology, Faculty of Veterinary Medicines, Tehran University, Tehran, Iran. ${ }^{2}$ Paraveterinary Faculty of Ilam, University of Ilam, Ilam, Iran. ${ }^{3}$ Department of Clinical Science, Faculty of Veterinary Medicine, Tehran University, Tehran, Iran.

Received: 17 October 2016 Accepted: 19 October 2016

Published online: 02 November 2016

\section{References}

1. Tavasoly A, Javanbakht J, Khaki F, Hosseini E, Barhami A, Hassan MA,

Mirabad M. Ulnar malignant peripheral nerve sheath tumour diagnosis in a mixed-breed dog as a model to study human: histologic, immunohistochemical, and clinicopathologic study. Diagn Pathol. 2013;8:86.

2. Pavarini P, Gomes DC, Bandinelli MB, Wouters F, Sonne L, Driemeier D, Farias da Cruz CE. Malignant peripheral nerve sheath tumor as a cause of chronic cardiac insufficiency in cattle. Acta Vet Scand. 2013;55:7.

3. Chijiwa K, Uchida K, Tateyama S. Immunohistochemical evaluation of canine peripheral nerve sheath tumors and other soft tissue sarcomas. Vet Pathol. 2004:41(4):307-18.

4. Park J-W, Woo G-H, Jee H, Jung D-W, Youn H-Y, Choi M-C, Kim D-Y, Malignant peripheral nerve sheath tumour in the liver of a dog. J Comp Pathol. 2011;144(2-3):223-6.

5. Fattahian $\mathrm{H}$, Mortazavi P, Moosavian $\mathrm{H}$, Mohyeddin $\mathrm{H}$, Moridpour R. Immunohistochemical study of a canine neurofibroma. J S Afr Vet Assoc 2012;83(1):18.

\footnotetext{
* Correspondence: javadjavanbakht@ut.ac.ir
}

'Department of Pathology, Faculty of Veterinary Medicines, Tehran University, Tehran, Iran 